\title{
UNIVERSITYOF
}

FORWARD

THINKING

WESTMINSTER ${ }^{\text {用 }}$

WestminsterResearch

http://www.westminster.ac.uk/westminsterresearch

\section{Distribution, occurrence and biotoxin composition of the main shellfish toxin producing microalgae within European waters: A comparison of methods of analysis}

McNamee, S.E., Medlin, L.K., Kegel, J., McCoy, G.R., Raine, R., Barra, L., Ruggiero, M.V., Kooistra, W.H.C.F., Montresor, M., Hagstrom, J., Pérez Blanco, E., Graneli, E., Rodríguez, F., Escalera, L., Reguera, B., Dittami, S., Edvardsen, B., Taylor, J., Lewis, J., Pazos, Y., Elliott, C.T. and Campbell, K.

NOTICE: this is the authors' version of a work that was accepted for publication in Harmful Algae. Changes resulting from the publishing process, such as peer review, editing, corrections, structural formatting, and other quality control mechanisms may not be reflected in this document. Changes may have been made to this work since it was submitted for publication. A definitive version was subsequently published in Harmful Algae, 55, 112-120, 2016.

The final definitive version in Harmful Algae is available online at:

https://dx.doi.org/10.1016/j.hal.2016.02.008

(c) 2016. This manuscript version is made available under the CC-BY-NC-ND 4.0 license http://creativecommons.org/licenses/by-nc-nd/4.0/

The WestminsterResearch online digital archive at the University of Westminster aims to make the research output of the University available to a wider audience. Copyright and Moral Rights remain with the authors and/or copyright owners. 
Whilst further distribution of specific materials from within this archive is forbidden, you may freely distribute the URL of WestminsterResearch: ((http://westminsterresearch.wmin.ac.uk/).

In case of abuse or copyright appearing without permission e-mail repository@westminster.ac.uk 
Distribution, occurrence and biotoxin composition of the main shellfish toxin producing microalgae within European waters: a comparison of methods of analysis

Sara E. McNamee ${ }^{1}$, Linda K. Medlin ${ }^{2}$, Jessica Kegel ${ }^{2}$, Gary R. McCoy ${ }^{3}$, Robin Raine ${ }^{3}$, Lucia Barra $^{4}$, Maria Valeria Ruggiero ${ }^{4}$, Wiebe H.C.F. Kooistra ${ }^{4}$, Marina Montresor ${ }^{4}$, Johannes Hagstrom $^{5}$, Eva Perez Blanco ${ }^{5}$, Edna Graneli ${ }^{5}$, Francisco Rodríguez $^{6}$, Laura Escalera ${ }^{6}$, Beatriz Reguera $^{6}$, Simon Dittami ${ }^{7}$, Bente Edvardsen ${ }^{7}$, Joe Taylor $^{8}$, Jane M. Lewis ${ }^{8}$, Yolanda Pazos ${ }^{9}$, Christopher T. Elliott ${ }^{1}$, Katrina Campbell ${ }^{1 *}$

${ }^{1}$ Institute for Global Food Security, School of Biological Sciences, Queen's University, Stranmillis Road, Belfast, BT9 5AG, UK

${ }^{2}$ Marine Biological Association of UK, The Laboratory, Citadel Hill, Plymouth, UK

${ }^{3}$ Martin Ryan Institute, National University of Ireland, Galway, Ireland

${ }^{4}$ Stazione Zoologica Anton Dohrn, Villa Comunale, 80121 Napoli, Italy,

${ }^{5}$ Linnaeus University, Marine Ecology Department, SE-39182 Kalmar, Sweden

${ }^{6}$ Instituto Español de Oceanografía, Subida a Radio Faro 50, 36390 Vigo, Spain

${ }^{7}$ University of Oslo, Department of Biosciences, 0316 Oslo, Norway

${ }^{8}$ Faculty of Science and Technology, University of Westminster, London W1W 6UW, UK

${ }^{9}$ INTECMAR, Peirao de Vilaxoán, Villagarcía de Arosa, 36611 Spain

\section{* Corresponding author}

Dr Katrina Campbell

Institute for Global Food Security, School of Biological Sciences, Queen's University, David Keir Building, Stranmillis Road, Belfast, UK BT9 5AG

Telephone: +44 (0) 2890976535, Fax: +44 (0) 2890976513

Email: katrina.campbell@qub.ac.uk 


\title{
Highlights
}

- Use of a multiplex biosensor for harmful algal toxin monitoring efforts in Europe.

- Toxin and species data compared for seawater samples $(n=256)$.

- Biosensor and RNA microarray more sensitive than light microscopy.

- Capability of being employed as an early warning detection system.

- Advanced solutions to algal biotoxin monitoring.

\begin{abstract}
Harmful algal blooms (HABs) are a natural global phenomena emerging in severity and extent. Incidents have many economic, ecological and human health impacts. Monitoring and providing early warning of toxic HABs are critical for protecting public health. Current monitoring programs include measuring the number of toxic phytoplankton cells in the water and biotoxin levels in shellfish tissue. As these efforts are demanding and labour intensive, methods which improve the efficiency are essential. This study compares the utilisation of a multitoxin surface plasmon resonance (multitoxin SPR) biosensor with enzyme-linked immunosorbent assay (ELISA) and analytical methods such as high performance liquid chromatography with fluorescence detection (HPLC-FLD) and liquid chromatography tandem mass spectrometry (LC-MS/MS) for toxic HAB monitoring efforts in Europe. Seawater samples $(n=256)$ from European waters, collected 2009 - 2011, were analysed for biotoxins: saxitoxin and analogues, okadaic acid and dinophysistoxins 1/2 (DTX1/DTX2) and domoic acid responsible for paralytic shellfish poisoning (PSP), diarrheic shellfish poisoning (DSP) and amnesic shellfish poisoning (ASP) respectively. Biotoxins were detected mainly in samples from Spain and Ireland. France and Norway appeared to have the lowest number of toxic samples. Both the multitoxin SPR biosensor and the RNA microarray were more sensitive
\end{abstract}


at detecting toxic HABs than standard light microscopy phytoplankton monitoring. A correlation between each of the detection methods were performed with the overall agreement, based on statistical $2 \times 2$ comparison tables, between each testing platform ranging between 32 $-74 \%$ for all three toxin families illustrating that one individual testing method may not be an ideal solution. An efficient early warning monitoring system for the detection of toxic HABs could therefore be achieved by combining both the multitoxin SPR biosensor and RNA microarray.

Keywords: Biotoxin; harmful algal bloom; microarray; biosensor; saxitoxin; okadaic acid; domoic acid.

\section{Introduction}

Monitoring programs in coastal waters have become a necessity because of the potential dangers to human health and the significant economic impacts of contaminated seafood from harmful microalgae. Monitoring of phytoplankton and their toxins are important to predict, manage and mitigate these effects. In Europe, the requirement for monitoring is established in a series of directives in which monitoring of coastal waters for the presence of potentially harmful phytoplankton is mandatory (Council Directive 91/492). The cost of this extensive monitoring program for phytoplankton and toxins is enormous. Traditionally phytoplankton in water are identified and enumerated by means of light microscopy. This technique requires a high degree of skill, taxonomic expertise and is time consuming with each sample requiring on average two hours to examine. This allows only 20 samples per week per person to be analysed (Medlin, 2013). The morphological similarity between different species within phytoplankton genera has meant that light microscopy alone is often insufficient to give definite species identifications (Trainer et al., 2012, John et al., 2014) or assess the potential toxicity of the 
water. For example, species of Pseudo-nitzschia and Alexandrium are often undistinguishable by light microscopy meaning it is often impossible to identify between toxic and non-toxic species (Barra et al., 2014). Unfortunately, many of these species are notorious for their ability to produce domoic acid or saxitoxin. The difficulty in determining their exact identification using light microscopy can have disastrous effects. Failure to detect a potentially toxic species is intolerable because of the possible consequences for human health. However, considering all species as potentially toxic is not an option either because of the economic consequences of closing a shellfish industry each time a Pseudo-nitzschia or Alexandrium species appear in the water.

Within Europe the most important marine biotoxins are the shellfish toxins causing PSP, DSP and ASP (Poletti et al., 2003). The Spanish Atlantic coast is subjected to extensive Pseudonitzschia australis, Dinophysis acuminata and Alexandrium minutum blooms annually during the upwelling season with Dinophysis acuta and Gymnodinium catenatum blooms occurring mainly during autumn downwelling (Trainer et al., 2010; Dittami et al., 2013). In the UK waters there are several species responsible for the production of biotoxins. In Scotland, shellfish contamination with biotoxins produced by harmful algal species belonging to Dinophysis, Pseudo-nitzschia and Alexandrium occur annually (Touzet et al., 2010). Several Pseudo-nitzschia species are found frequently in Scottish waters including P. delicatissima, $P$. calliantha, P. pseudodelicatissima. P. australis, $P$. seriata and occasionally $P$. multiseries, $P$. pungens and P. americana (Fehling et al., 2006; Hall and Frame, 2010). The accumulation of domoic acid in shellfish has led to shellfish harvesting closures in Western Scottish waters since 1999 (Fehling et al., 2006). In recent years shellfish containing domoic acid and DSP toxins have been reported in France, UK, Spain, Ireland and Portugal (Campbell et al., 2001; Vale and Sampayo, 2001; James et al., 2005; Blanco et al., 2006; Villar-Gonzalez et al., 2007; Vale et al., 2008; Fux et al., 2009; Hossen et al., 2011). 
The project MIDTAL was a FP7 funded EU project with the overall aim of improving national monitoring capabilities for toxin producing phytoplankton species and their toxins in water. The multitoxin SPR biosensor encompasses three of the most commonly detected biotoxin groups in European waters; saxitoxin (and analogues), okadaic acid (including DTX1/DTX2) and domoic acid (McNamee et al., 2013). For phytoplankton species identification a RNA microarray was designed using rRNA probes for the identification of potentially harmful species (Barra et al., 2014; Dittami et al., 2013; Edvardsen et al., 2013; Kegel et al., 2013; McCoy et al., 2013; Taylor et al., 2013). The aim of this study was to evaluate the occurrence and distribution of marine biotoxins in European waters during 2009-2011 utilising the multitoxin SPR biosensor in comparison to the conventional approaches of ELISA and analytical detection of toxins such as HPLC or LC-MS/MS. The correlation of the toxin occurrence was in turn investigated with light microscopy and the RNA microarray for detection of biotoxin producing species.

\section{Materials and methods}

\subsection{Instrumentation}

The prototype multitoxin SPR biosensor was developed by GE Healthcare (Uppsala, Sweden). An Acquity UPLC system coupled to a Quattro Premier XE mass spectrometer (Waters, Ireland) was used for analysis of okadaic acid and domoic acid. For the separation, identification and quantification of the individual PSP toxin analogues a Waters alliance 2695 separation module HPLC system equipped with a Waters 2475 fluorescence detector (Waters, Ireland) was employed.

\subsection{Reagents}


Saxitoxin and analogues (dcSTX, NEO, dcNEO, GTX1/4, GTX2/3, GTX5, dcGTX2/3, C1/2), okadaic acid, DTX1, DTX2 and domoic acid were purchased from the National Research Council Canada (NRCC, Halifax, Canada). HBS-EP ${ }^{+}$buffer was purchased from GE Healthcare (Buckinghamshire, UK). Acetonitrile, $\mathrm{HCl}, \mathrm{NaOH}$, SDS, formic acid, ammonium hydroxide and ammonium formate were purchased from Sigma-Aldrich (Dorset, UK). ELISA kits for the analysis of domoic acid (ref. code E.F.1), okadaic acid (ref. code E.F.2) and saxitoxin (ref. code E.F.3) were developed and provided by Centre d'Economie Rurale (CER, Belgium). Natural seawater (salinity 33-34 ppt) was obtained from Strangford Lough (Co. Down, NI, UK).

\subsection{Seawater sample collection}

Seawater samples were collected during 2009-2011 $(n=256)$ from a number of sites across Europe as part of the MIDTAL project. Seawater samples were collected by MIDTAL partners in triplicate, duplicate or singly. Triplicate: Stazione Zoologica 'A. Dohrn' di Napoli (SZN), Naples, Italy (Gulf of Naples); Linnaeus University (LNU), Kalmar, Sweden (Skagerrak area, Sweden); Instituto Español de Oceanografia (IEO), Vigo, Spain (Ría of Pontevedra, Spain); University of Oslo (UO), Oslo, Norway (Oslofjord, Norway); University of Westminster (UW), London, UK (Orkney Islands, Scotland). Duplicate: Martin Ryan Institute, National University of Ireland (NUIG), Galway, Ireland (Killary, Cork and Bell Harbours, Ireland) Singly: Marine Biological Association (MBA), Plymouth, UK (Arcachon Bay, France); Technological Institute for the marine environment control of Galicia (INT), Pontevedra, Spain (Rias of Pontevedra, Arosa, Muros, Ares-Betanzos, and estuary of Bayona, Spain). The seawater samples were filtered through a $0.45 \mu \mathrm{m}$ nitrocellulose filter until the filter clogged (approximately 0.5-2 L). The filter with seston (plankton and non-living matter) was frozen in a $2 \mathrm{ml}$ eppendorf tube at $-20^{\circ} \mathrm{C}$ and shipped to Queen's University Belfast for further extraction 
and analysis for saxitoxin (and analogues), okadaic acid (including DTX1/DTX2) and domoic acid.

\subsection{Sample preparation and lysis}

The frozen filter was thawed and toxins extracted using $2 \mathrm{ml}$ deionised water (with the exception that MIDTAL partner NUIG was extracted in $5 \mathrm{ml}$ ) by vortexing for $20 \mathrm{~s}$, mixing end over end for $20 \mathrm{~min}$, bead beating with $0.5 \mathrm{~mm}$ glass beads $(1 \mathrm{~g})$ for $20 \mathrm{~min}$ on a Merris minimix shaker (Merris Engineering Ltd, Ireland) followed by centrifugation at $3000 \mathrm{~g}$ for 10 min. Finally, the supernatant was filtered using a $0.45 \mu \mathrm{m}$ syringe filter.

\subsection{Sample analysis and comparison}

Seawater samples $(n=256)$ were analysed for toxins using three testing platforms: multitoxin SPR biosensor, ELISA and analytical methods including HPLC-FLD or LC-MS/MS. Depending on the method of analysis, extracts were diluted 1:1 with corresponding buffers; $\mathrm{HBS} \mathrm{EP}^{+}$buffer for the multitoxin SPR (analysed in quadruplicate), ELISA dilution buffer for the ELISA (analysed in duplicate) or analysed neat for the analytical methods (analysed in duplicate). In addition, samples were analysed by the RNA microarray and cell counts were performed by light microscopy to determine what species of phytoplankton were present in each sample.

\subsection{Multitoxin SPR biosensor methodology}

The multitoxin SPR biosensor was optimised and discussed in full in previous research paper (McNamee et al., 2013). Briefly, the multitoxin SPR sensor chip was optimised on the prototype multiplex SPR biosensor. The flow rate across the chip surface was $20 \mu 1 / \mathrm{min}$ and sample contact time was 8 min. Report points were taken $10 \mathrm{~s}$ before injection and $30 \mathrm{~s}$ after 
injection to determine baseline and level of binding on the chip surface. The saxitoxin, okadaic acid and domoic acid antibodies were diluted and mixed 1:1 with samples or standards. The surface of the sensor chip was finally regenerated for $60 \mathrm{~s} \mathrm{(30} \mathrm{s} \mathrm{x} \mathrm{2)} \mathrm{before} \mathrm{analysis} \mathrm{of} \mathrm{the} \mathrm{next}$ sample. Regeneration solutions for saxitoxin, okadaic acid and domoic acid were $10 \mathrm{mM} \mathrm{HCl} / 1$ $\% \operatorname{SDS}(1: 1, \mathrm{v} / \mathrm{v}), 250 \mathrm{mM} \mathrm{NaOH} /$ acetonitrile $(8: 2, \mathrm{v} / \mathrm{v})$ and $100 \mathrm{mM} \mathrm{HCl} / 1 \% \operatorname{SDS}(1: 1, \mathrm{v} / \mathrm{v})$ respectively. The duration of sample analysis including regeneration of the chip was approximately $13 \mathrm{~min}$ for each sample.

\subsection{ELISA methodology}

Three separate ELISA kits were used for the detection of saxitoxin, okadaic acid and domoic acid. The reagents were prepared and the methods were followed as described in the ELISA manufacturer's protocol (CER, Belgium) and previous publication (Dubois et al., 2010) with the exception that the calibration standards were made up in ELISA dilution buffer/deionised water $(1: 1)$. Standards or samples $(50 \mu 1)$ were applied to the pre-coated purified sheep antirabbit IgG microtitre plates. Diluted peroxidase conjugate $(100 \mu \mathrm{l})$ and reconstituted antibody $(100 \mu \mathrm{l})$ were applied to all wells and incubated at $+4{ }^{\circ} \mathrm{C}$ for $2 \mathrm{hr}$ (okadaic acid and domoic acid ELISA) or overnight (saxitoxin ELISA). The wells were emptied and washed three times (okadaic acid and domoic acid ELISA) or five times (saxitoxin ELISA) with washing buffer. Peroxide/TMB $(150 \mu \mathrm{l})$ was added to each well and incubated for $30 \mathrm{~min}$ in the dark at room temperature. Finally, $6 \mathrm{M}$ sulphuric acid $(50 \mu \mathrm{l})$ was added to each well to stop the reaction and the absorbance was read at $450 \mathrm{~nm}$ within 30 min using a Tecan plate reader (Tecan UK Ltd, Reading, UK).

\subsection{Analytical methodology}


Total okadaic acid toxins (including DTX1 and DTX2) or total PSP toxins based on individual concentrations were calculated for each sample. Three individual conventional analytical methods were employed for the detection of the three toxin groups as follows:

LC-MS/MS: Okadaic acid (including DTX1 and DTX2): Samples were analysed for okadaic acid, DTX1 and DTX2 by LC-MS/MS following the standard operating procedure by the European Union Reference Laboratory for Marine Biotoxins (EU-RL-MB, Version 4, July 2011).

LC-MS/MS: Domoic acid: Samples were analysed for domoic acid by LC-MS/MS following the standard operating procedure by the European Union Reference Laboratory for Marine Biotoxins (EU-RL-MB, Version 1, February 2010).

HPLC-FLD: Saxitoxin (and analogues): Samples were analysed for saxitoxin analogues (C1/2, GTX2/3, STX, GTX1/4, dcNEO, NEO, dcGTX2/3, dcSTX, GTX5) by HPLC-FLD following a modification of the pre-column oxidation Lawrence AOAC official method (Lawrence et al., 2005).

\subsection{RNA microarray methodology}

The RNA microarray was optimised and discussed in full in previous research papers (Lewis et al. 2012; Dittami et al., 2013; Edvardsen et al., 2013; Kegel et al., 2013; McCoy et al., 2013; Taylor et al., 2013; Barra et al., 2014). A correlation between the toxins detected and the species present as determined by the RNA microarray was performed.

\subsection{Light microscopy methodology}

Toxic phytoplankton species detected in seawater samples was discussed in full in previous research papers (Dittami et al., 2013; Edvardsen et al., 2013; Kegel et al., 2013; McCoy et al., 
2013; Taylor et al., 2013; Barra et al., 2014). A correlation between the toxins detected and the species detected by light microscopy was performed.

\section{Results and Discussion}

Seawater samples $(n=256)$ were collected between 2009 and 2011 across seven European countries by eight partners within the MIDTAL project for analysis of marine biotoxins and toxic phytoplankton. HAB species can be part of an assemblage of co-occurring species and are often recurring when water conditions are favourable to which they have adapted. Change in community structure can have important implications for water and aquaculture management. Diatom (e.g. Pseudo-nitzschia) growth is favoured during high nutrient, turbulent conditions of spring-time upwelling periods (Silva et al., 2009). Whereas stratified conditions of summer and autumn downwelling favour a shift to the dinoflagellates (e.g. Gymnodinium catenatum and Dinophysis) which are adapted to these conditions by their ability to migrate through the water (Ryan et al., 2008). Changes in phytoplankton community structure and history can lead to changes in algal toxin occurrence therefore the simultaneous determination of several classes of algal toxins is a powerful and direct tool for monitoring of toxic algal presence. Analysing seawater samples over a two year monitoring period in Europe has found that toxic samples were received (mainly) from Spain and Ireland with significant levels of all three key toxins detected in these regions. Gulf of Naples (SZN, Italy) showed higher levels of domoic acid toxins in their seawater samples compared to the other key toxins, while okadaic acid toxins were more prevalent in the Oslofjorden area (UO, Norway) although levels were not particularly high $(0.5-2 \mathrm{ng} / \mathrm{L})$.

\subsection{Sampling plan}


The volume of seawater samples that was filtered by each partner varied from approximately 0.5-2 L with the volume depending on the time of year and level of phytoplankton in the water (until the filter clogged). In some instances, variations in toxin levels were observed between replicate samples. This can be attributed to the heterogeneous distribution of phytoplankton in the water samples. Different levels of phytoplankton may be collected on each filter between replicate samples unless continuous swirling of the seawater sample was carried out during filtering, but also due to stochastic events at low cell concentrations, thus leading to variability in the toxin concentrations detected. A better approach may have been to filter a specified volume of seawater, which would have added some continuity to the sampling plan. However, the current sampling plan did allow the concentration of toxins during times of the year when levels of phytoplankton in the water were low and therefore allowed the trace level determination of toxins in the water. It is also worth noting that sampling was much more frequent in Spain as well as a slightly different filtering protocol meaning that the Spanish samples correspond to a higher volume of seawater making it much easier to detect toxins

\subsection{Sample analysis}

Analysis of saxitoxin (and analogues), okadaic acid (and DTX1/DTX2) and domoic acid toxins were performed using multitoxin SPR, ELISA and analytical methods (HPLC-FLD or LCMS/MS) for a comparative evaluation. A comparison of the key features (Table 1) and a summary of the results for each method applied for toxin and species identification (RNA microarray and cell counts) are provided (Table 2). The key features include sensitivity, specificity, ease of use, speed of analysis, portability and cost. Although many analytical methods are available it is acknowledged that these methods require skilled personnel and are labour intensive because of complex toxin profiles with many methods measuring only one toxin family. Additionally, development of new methods can be hindered by lack of certified 
standards. Immunological assays, such as ELISAs, have shown promise as sensitive rapid screening tools, however, are often lacking multiplexing and portability capabilities. The emergence of biosensor based immunological assays in the field of marine biotoxin testing has demonstrated many advantages including high sensitivity, specificity and robustness. Toxin biosensors, such as the multitoxin SPR biosensor, are the state of the art technology for analysing seawater and water samples for the presence and semi-quantitative screening of algal biotoxins. They provide rapid, sensitive analysis and have the possibility of multiplex detection for direct coastal monitoring of toxin producing algae. Most partners within the MIDTAL project collected samples once a month, however, sampling was much more frequent in Galicia, Spain (IEO and INT collected samples once a week during the HAB season, MayNovember). The main interest at IEO are Dinophysis species which are very scarce most of the year therefore pre-concentrated samples were used to filter the final samples required for sample extractions. IEO and INT samples, therefore, correspond to a much higher volume of seawater and it was much easier (and frequent) to detect toxins. This explains the higher percentage of positive results and higher levels of toxins in these areas.

\subsection{Domoic acid}

\subsubsection{Toxin analysis}

The levels of domoic acid in the waters for all sampling sites in Europe over their sampling periods were examined. Differences in the dynamic range of the calibration curve for each toxin testing platform meant that if samples contained high levels of domoic acid the concentration reported could only be greater than the highest standard, times the dilution. For multitoxin SPR this was $100 \mathrm{ng} / \mathrm{ml}$ and for ELISA this was $40 \mathrm{ng} / \mathrm{ml}$. For semi-quantitative levels of domoic acid, those samples that exceeded the highest standard would need diluted and re-analysed. Actual concentrations of domoic acid between the three testing platforms will 
therefore differ, however, correlations were still visible. The results for the detection of domoic acid and domoic acid producing species are presented in Table 2. Samples $(n=256)$ were analysed for domoic acid by three toxin testing platforms with $64 \%, 75 \%$ and $44 \%$ samples positive for domoic acid by multitoxin SPR, ELISA and LC-MS/MS respectively (Table 2). Differences were due to the sensitivity of the different testing platforms (Table 1) with the domoic acid ELISA being the most sensitive with a limit of detection (LOD) of $0.34 \mathrm{ng} / \mathrm{ml}$ compared to $1.66 \mathrm{ng} / \mathrm{ml}$ (multitoxin SPR) and $2.5 \mathrm{ng} / \mathrm{ml}$ (LC-MS/MS). This reflects the number

of positive samples by each detection method (Figure 1). All countries in Europe that were analysed showed some level of domoic acid in their waters. The lowest percentage of samples as confirmed by LC-MS/MS containing domoic acid were found in France (11\%) and Norway (14\%). The highest percentage of domoic acid as confirmed by LC-MS/MS were found in Spain by both Spanish partners, IEO (93\%), INT (67 \%) and also by SZN in Italy (57 \%). There was little variation in the percentage toxic samples in Spain between the three toxin testing platforms probably because the samples contained quite high levels of domoic acid and therefore the LODs were not an issue. In most countries the percentage toxic samples was lower when analysed by multitoxin SPR and even lower by LC-MS/MS due to the sensitivity and LODs for each detection system.

\subsubsection{Algal species analysis}

Samples $(n=145)$ were analysed by the RNA microarray for potentially toxic domoic acid producing species belonging to Pseudo-nitzschia with positive results detected in $75 \%$ samples (Table 2). The RNA microarray detected both genus and species level probes for Pseudonitzschia with a large number of Pseudo-nitzschia species detected including P. multistriata, $P$. seriata, $P$. delicatissima, $P$. multiseries, $P$. calliantha, $P$. pungens and $P$. fraudulenta. Only 
$3 \%$ of samples were positive for domoic acid toxins by the multitoxin SPR (and ELISA) that did not show a potentially toxic domoic acid producing species by the RNA microarray. Samples $(n=177)$ analysed by light microscopy for phytoplankton species displayed $77 \%$ of samples with a potentially toxic domoic acid producing species (Table 2). Twelve species of Pseudo-nitzschia have been documented to produce domoic acid that causes ASP (Moestrup et al., 2009). As species of Pseudo-nitzschia are extremely difficult and often impossible to differentiate by light microscopy, many partners reported identifications to the genus level only or identified by size classes (wide for seriata group and narrow for delicatissima group). There were only $8 \%$ of samples that were positive for domoic acid toxins by the multitoxin SPR that did not show a Pseudo-nitzschia species present by light microscopy. This highlights that multitoxin SPR and RNA microarrays could be more efficient in detecting the presence of toxins/presence of HAB species than traditional methods of monitoring phytoplankton and therefore used as an early warning monitoring tool.

\subsection{Okadaic acid (including DTX1 and DTX2)}

\subsubsection{Toxin analysis}

The levels of okadaic acid (and DTX1/DTX2) in the waters for all sampling sites in Europe over their sampling periods were examined. Differences in calibration curves for each testing platform meant that if samples contained high levels of okadaic acid the concentration reported could only be greater than the highest standard times the dilution. For SPR this was $20 \mathrm{ng} / \mathrm{ml}$ and for ELISA this was $40 \mathrm{ng} / \mathrm{ml}$. Actual concentrations of okadaic acid between the three testing platforms will therefore differ, however, correlations are still visible. The results for the detection of okadaic acid (and analogues) and okadaic acid producing species are presented in Table 2. Samples $(n=256)$ were analysed for okadaic acid (and DTX1/DTX2) by three toxin testing platforms with $58 \%, 61 \%$ and $31 \%$ of samples positive for okadaic acid by multitoxin 
SPR, ELISA and LC-MS/MS respectively (Table 2). Multitoxin SPR and ELISA show similar LODs at 0.36 and $0.41 \mathrm{ng} / \mathrm{ml}$ respectively (Table 1 ) reflecting the number of positive samples by these two testing platforms being so similar (Figure 1). The slight differences may be caused by the cross-reactivity profiles of the two antibodies used in the multitoxin SPR and ELISA. Multitoxin SPR shows cross-reactivity of $68 \%$ and $65 \%$ for DTX1 and DTX2 compared to $78 \%$ and $2.6 \%$ for these two analogues by ELISA (Dubois et al., 2010; McNamee et al., 2013). Spain and Ireland were the only countries in Europe to show DTX2 in their water samples with five samples from Spain and two samples from Ireland positive for DTX2. No DTX1 was found in any water sample in Europe that was examined therefore the differences must be attributed to DTX2. Differences between multitoxin SPR and ELISA with LC-MS/MS are because of the sensitivity of the different testing platforms with the LC-MS/MS showing a LOD approximately six times higher than the other two testing platforms at $2.5 \mathrm{ng} / \mathrm{ml}$. The percentage of toxic samples for Ireland were slightly higher for multitoxin SPR (76 \%) compared to ELISA (64\%). This was caused by DTX2 being detected in a number of samples from NUIG (Ireland). When analysed by LC-MS/MS all samples showed less positive results for okadaic acid (due to LOD of $2.5 \mathrm{ng} / \mathrm{ml}$ ) except for those from IEO (Spain). Results for the Spanish samples are very similar across the three testing platforms probably because the level of okadaic acid in the samples was much higher and therefore sensitivity was not an issue. Okadaic acid toxins appear to be more prevalent in Spain with both Spanish partners detecting significant levels over the two year sampling period. Spain showed the greatest percentage of samples positive for okadaic acid with $96 \%$ and $49 \%$ for IEO and INT respectively confirmed by LC-MS/MS, whereas, France (0 \%), Italy (4\%) and UK (9 \%) showed the lowest.

\subsubsection{Algal species analysis}


Samples $(n=145)$ were analysed by the RNA microarray for potentially toxic okadaic acid producing species belonging to Dinophysis or Prorocentrum lima with positive results detected in $39 \%$ samples (Table 2). The RNA microarray detected both genus and species level probes for Dinophysis and Prorocentrum with P. lima, D. acuta, D. acuminata, D. caudata, D. sacculus, $D$. fortii and $D$. norvegica being the most common potentially toxic species detected. Samples $(23 \%)$ were positive for okadaic acid toxins by multitoxin SPR and ELISA that did not show a potentially toxic okadaic acid producing species present by the RNA microarray suggesting that the multitoxin SPR biosensor is a more sensitive detection system.

Samples $(n=177)$ were also analysed by light microscopy for phytoplankton species with 58 $\%$ of samples showing a potentially toxic okadaic acid producing species (Table 2). Both Dinophysis and Prorocentrum were detected by light microscopy with species identified including D. acuta, D. acuminata and D. norvegica being most common. Samples (17\%) were positive for okadaic acid by the multitoxin SPR and ELISA that did not show a potentially toxic okadaic acid producing species present by light microscopy. Again in the case of okadaic acid and related toxins, both the multitoxin SPR and the RNA microarray are more sensitive at detecting toxic $\mathrm{HABs}$ as an early warning detection tool than light microscopy following standard monitoring protocols.

\subsection{Saxitoxin (and analogues)}

\subsubsection{Toxin analysis}

The levels of saxitoxin (and analogues) in the waters for all sampling sites in Europe over their sampling periods were examined. Differences in calibration curves for each testing platform meant that if samples contained high levels of saxitoxin the concentration reported could only be greater than the highest standard times the dilution. For multitoxin SPR this was $40 \mathrm{ng} / \mathrm{ml}$ and for ELISA this was $0.8 \mathrm{ng} / \mathrm{ml}$. Actual concentrations of saxitoxin between the three testing 
platforms will therefore differ, however, correlations were still visible. Overall, antibody based methods for saxitoxin show much better sensitivity and particularly to a range of analogues. Very low levels of a few saxitoxin toxins would accumulate and be detected as saxitoxin equivalents by antibody methods such as ELISA and multitoxin SPR but as individual saxitoxin toxins will not show up by HPLC-FLD. The results for the detection of saxitoxin (and analogues) and saxitoxin producing species are presented in Table 2. Samples $(n=256)$ were analysed for saxitoxin and analogues by three toxin testing platforms with $48 \%, 89 \%$ and 22 $\%$ of samples testing positive for saxitoxin (or analogues) by multitoxin SPR, ELISA and HPLC-FLD respectively (Table 2). Discrepancies between results are caused by the ultraenhanced sensitivity of the ELISA with the saxitoxin ELISA showing a LOD of $0.01 \mathrm{ng} / \mathrm{ml}$. In comparison, the LODs for multitoxin SPR and HPLC-FLD were $0.83 \mathrm{ng} / \mathrm{ml}$ and $2.5 \mathrm{ng} / \mathrm{ml}$ respectively (Table 1). This reflects the number of positive samples by each detection method (Figure 1). Differences observed can be attributed to the LODs and cross-reactivity profiles of the antibodies used in the multitoxin SPR and ELISAs (Dubois et al., 2010; McNamee et al., 2013). The percentage of toxic samples by multitoxin SPR was considerably less for many partners except for Spain (IEO) and Ireland (NUIG), possibly because the levels of saxitoxin were much higher in these areas and so sensitivity was not an issue. Many of the samples showed very low levels of saxitoxin (less than $2.5 \mathrm{ng} / \mathrm{L}$ ) and so this HPLC-FLD method is not a viable detection method for the early warning of saxitoxin in seawater samples. No PSP analogues were found in any seawater sample from France or Norway when analysed by HPLC-FLD. In comparison all nine saxitoxin analogues (included in this HPLC-FLD method) were found in Spain. C1/2 and GTX2/3 were the most predominant analogues found in Sweden (LNU), Ireland (NUIG) and the UK (UW) while only GTX2/3 was found in Italy (SZN).

\subsubsection{Algal species analysis}


Samples $(n=145)$ were analysed by the RNA microarray for potentially toxic PSP toxin producing species belonging to Alexandrium or Gymnodinium with positive results detected in $37 \%$ samples (Table 2). The RNA microarray detected both genus and species level probes for Alexandrium with A. minutum and A. tamarense being most common. A. ostenfeldii was only detected in two samples. Both genus and species level probes were also detected for Gymnodinium and G. catenatum. Samples (18\%) were positive for PSP toxins by multitoxin SPR that did not show a potentially toxic PSP toxin producing species present by the RNA microarray. This highlights the enhanced sensitivity of the multitoxin SPR method.

Samples $(\mathrm{n}=177)$ analysed by light microscopy for phytoplankton species showed $37 \%$ of samples with a potentially toxic saxitoxin producing species (Table 2). Due to the difficulty in differentiating some phytoplankton to species level using light microscopy many partners only reported taxa identified to the genus level, i.e. Alexandrium and Gymnodinium species were detected. Although some partners did confirm the most common belonged to A. minutum and A. tamarense as well as G. catenatum. Samples (19\%) were positive for PSP toxins by multitoxin SPR and ELISA that did not show a potentially toxic PSP producing species present by light microscopy. Therefore both multitoxin SPR and the RNA microarray are more sensitive at detecting toxic $\mathrm{HABs}$ as an early warning detection tool than light microscopy.

\subsection{Correlation of testing platforms}

Table 2 shows the qualitative data for seawater samples when analysed for domoic acid, okadaic acid and PSP toxins analysed using multitoxin SPR, ELISA, analytical (HPLC-FLD or LC-MS/MS), RNA microarray and cell counts by light microscopy. Some samples were not analysed by the RNA microarray and light microscopy due to sample and time limitations. Statistical 2 × 2 comparative analyses were performed for the sample data between each of the testing platforms (Table 3) based on whether the sample was determined to be positive (+) or 
negative (-). Positive samples for multitoxin SPR and ELISA were based on a result higher than the $\mathrm{IC}_{20}$ of the assay. Positive samples for the analytical methods were based on a detectable peak being visible and finally positive samples for the RNA microarray and light microscopy were based on the presence of a potentially toxic species being identified.

For domoic acid analysis, the highest overall agreement was found between ELISA and RNA (74\%), however, the overall agreement between multitoxin SPR and ELISA (71\%), multitoxin SPR and analytical (69 \%), multitoxin SPR and RNA (67\%), ELISA and analytical (69 \%) and RNA and cell counts (71\%) were also all very similar. The lowest overall agreement was found between analytical and RNA (54\%). For okadaic acid analysis, the highest overall agreement was found between multitoxin SPR and ELISA (70 \%). This is reflected by the LODs for these two methods being so similar at $0.36 \mathrm{ng} / \mathrm{ml}$ (multitoxin SPR) and $0.41 \mathrm{ng} / \mathrm{ml}$ (ELISA). The overall agreement between all other methods ranged between approximately 56 - $66 \%$ with the lowest overall agreement found between multitoxin SPR and RNA (56\%). For PSP toxins analysis, the highest overall agreement was found between multitoxin SPR and analytical $(73 \%)$. The overall agreement between all other methods ranged between approximately $32-66 \%$. The lowest overall agreement was found between ELISA and analytical (32\%). This is because of the significant difference in LODs between these two methods, ELISA $(0.01 \mathrm{ng} / \mathrm{ml})$ and analytical $(2.5 \mathrm{ng} / \mathrm{ml})$ with the ELISA for PSP toxins being ultra-sensitive.

A number of different testing platforms were examined to include both toxin and species determination in seawater samples in Europe over a two year period. The overall agreement obtained between all testing platforms is significant because it proves that none of the current testing methods are perfect solutions for toxin analysis in water samples. Analytical methods are not sensitive enough with extensive sample collection and concentration, are time consuming and require skilled personnel. ELISA methods show the desired sensitivity but 
currently lack multiplexing and portability capabilities. This data illustrates that by combining both the multitoxin SPR and RNA microarray a more efficient early warning monitoring system for the detection of toxic microalgae could be established.

\section{Conclusion}

There is a need to ensure fast and reliable identification of toxins and toxic phytoplankton. Detection approaches for harmful species and biotoxins need to be inexpensive, rapid, accurate and easy to use. False negative results are dangerous to humans, whereas false positive results will have serious consequences for the shellfish industry. The testing platforms examined in this research proves with statistical comparisons that there is no one testing method that is completely fit for purpose. Microarrays such as the multitoxin SPR biosensor for toxin analysis and the RNA microarray for toxic species detection are the state of the art technology for analysing samples, which show excellent potential for monitoring programs. They offer high sample throughput with more accurate and reliable identification thereby reducing human error when using light microscopy. The shellfish and water industries require assistance in order to mitigate the consequences of such toxic episodes as the problems caused by toxicity of our waters and shellfish will never go away. A possible solution to this issue could be achieved by combining both the multitoxin SPR biosensor and RNA microarrays for a more efficient early warning monitoring system for the detection of toxic microalgae. The techniques used in this research show a potential for improving the speed and accuracy in the identification of harmful algae species and their toxins. The multitoxin SPR biosensor lacks portability. Therefore, to further this research a large scale evaluation of portable low cost diagnostics, miniaturisation of SPR sensors or alternative microarrays for field diagnostics would be opportune.

\section{Acknowledgements}


This research was funded by the European Commission as part of FP7 European project MIDTAL, grant number 201724, the Advanced ASSET project, partly funded through InvestNI and from the European Sustainable Programme 2007-2013 under the European Regional Development Fund (“ERDF”). I gratefully acknowledge all partners in the MIDTAL project for their contribution to this study with RNA microarray, microscopy data and for collecting and providing seawater samples from around Europe. Jixin Chen (MBA), Lourdes Velo-Suárez (IEO), Wenche Eikrem and Vladyslava Hostyeva (UO) and Marco Berzano (UW).

\section{References}

Barra, L., Ruggiero, M.V., Chen, J., Kooistra, W.C.H.F., 2014. Specificity of LSU rRNAtargeted oligonucleotide probes for Pseudo-nitzschia species tested through dot-blot hybridisation. Environ. Sci. Pollut. Res. 21, 548-557.

Blanco, J., Cano, J., Mariño, M.D.C., Campos, M.J., 2006. Effect of phytoplankton containing paralytic shellfish and amnesic shellfish toxins on the culture of the king scallop Pecten maximus in Malaga (SE Spain). Aquat. Living Resour. 19, 267-273.

Campbell, D.A., Kelly, M.S., Busman, M., Bolch, C.J., Wiggins, E., Moeller, P.D.R., Morton, S.L., Hess, P., Shumway, S.E., 2001. Amnesic shellfish poisoning in the king scallop, Pecten maximus, from the west coast of Scotland. J. Shellfish Res. 20, 75-84.

Dittami, S.M., Pazos, Y., Laspra, M., Medlin, L.K., 2013. Microarray testing for the presence of toxic algae monitoring programme in Galicia (NW Spain). Environ. Sci. Pollut. Res. 20, 6778-6793. 
Dubois, M., Demoulin, L., Charlier, C., Singh, G., Godefroy, S.B., Campbell, K., Elliott, C.T., Delahaut, P., 2010. Development of ELISAs for detecting domoic acid, okadaic acid, and saxitoxin and their applicability for the detection of marine toxins in samples collected in Belgium. Food Additives and Contaminants Part A-Chemistry Analysis Control Exposure \& Risk Assessment. 27, 859-868.

Edvardsen, B., Dittami, S.M., Groben, R., Brubak, S., Escalera, L., Rodriguez, F., Reguera, B., Chen, J., Medlin, L.K., 2013. Molecular probes and microarrays for the detection of toxic algae in the genera Dinophysis and Phalacroma (Dinophyta). Environ. Sci. Pollut. Res. 20, 67336750.

Edler, L., and Elbrächter, M., 2010. The Utermöhl method for quantitative phytoplankton analysis. In Microscopic and molecular methods for quantitative phytoplankton analysis (Karlson B, Cusack CK \& Bresnan E, eds), 13-20. IOC Manuals and Guides n. 55.

Fehling, J., Davidson, K., Bolch, C., Tett, P., 2006. Seasonality of Pseudo-nitzschia spp. (Bacillariophyceae) in western Scottish waters. Mar. Ecol. Prog. Ser. 323, 91-105.

Fux, E., Bire, R., Hess, P., 2009. Comparative accumulation and composition of lipophilic marine biotoxins in passive samplers and in mussels (M. edulis) on the West Coast of Ireland. Harmful Algae. 8, 523-537.

Hall, A.J., Frame, E., 2010. Evidence of domoic acid exposure in harbour seals from Scotland: A potential factor in the decline in abundance? Harmful Algae. 9, 489-493. 
Hossen, V., Jourdan-da Silva, N., Guillois-Becel, Y., Marchal, J., Krys, S., 2011. Food poisoning outbreaks linked to mussels contaminated with okadaic acid and ester dinophysistoxin-3 in France, June 2009. Eurosurveillance. 16, 15-21.

James, K.J., Gillman, M., Amandi, M.F., Lopez-Rivera, A., Puente, P.F., Lehane, M., Mitrovic, S., Furey, A., 2005. Amnesic shellfish poisoning toxins in bivalve molluscs in Ireland. Toxicon. 46, 852-858.

John, U., Litaker, W., Montresor, M., Murray, S., Brosnahan, M., Anderson, D.M., 2014. Formal revision of the Alexandrium tamarense species complex (Dinophyceae) taxonomy: the introduction of five species with emphasis on molecular-based (rDNA) classification. Protist $165,779-804$

Kegel, J.U., Del Amo, Y., Medlin, L.K., 2013. Introduction to project MIDTAL: its methods and samples from Arcachon Bay, France. Environ. Sci. Pollut. Res. 20, 6690-6704.

Lawrence, J.F., Niedzwiadek, B., Menard, C., 2005. Quantitative determination of paralytic shellfish poisoning toxins in shellfish using prechromatographic oxidation and liquid chromatography with fluorescence detection: Collaborative study. J. AOAC Int. 88, 17141732.

Lewis, J., Medlin, L.K., Raine, R., 2012. MIDTAL (Microarrays for the Detection of Toxic Algae): A Protocol for a Successful Microarray Hybridisation and Analysis. Koeltz Publishing. 
McCoy, G.R., Touzet, N., Fleming, G.T.A., Raine, R., 2013. An evaluation of the applicability of microarrays for monitoring toxic algae in Irish coastal waters. Environ. Sci. Pollut. Res. 20, 6751-6764.

McCoy, G.R., McNamee, S., Campbell, K., Elliott, C.T., Fleming, G.T.A., Raine, R., 2014. Monitoring a toxic bloom of Alexandrium minutum using novel microarray and multiplex surface plasmon resonance biosensor technology. Harmful Algae. 32, 40-48.

McNamee, S.E., Elliott, C.T., Delahaut, P., Campbell, K., 2013. Multiplex biotoxin surface plasmon resonance method for marine biotoxins in algal and seawater samples. Environ. Sci. Pollut. Res. 20, 6794-6807.

Medlin, L., 2013. Molecular tools for monitoring harmful algal blooms. Environ. Sci. Pollut. Res. 20, 6683-6685.

Moestrup, Ø., Akselman, R., Cronberg, G., Elbraechter, M., Fraga, S., Halim, Y., Hansen, G., Hoppenrath, M., Larsen, J., Lundholm, N., Nguyen, L. N., Zingone, A. (Eds) (2009 onwards). IOC-UNESCO Taxonomic Reference List of Harmful Micro Algae. Available online at http://www.marinespecies.org/HAB. Accessed on 2015-01-29.

Poletti, R., Milandri, A., Pompei, M., 2003. Algal biotoxins of marine origin: New indications from the European Union. Vet. Res. Commun. 27, 173-182. 
Ryan, J.P., Gower, J.F.R., King, S.A., Bissett, W.P., Fischer, A.M., Kudela, R.M., Kolber, Z., Mazzillo, F., Rienecker, E.V., Chavez, F.P., 2008. A coastal ocean extreme bloom incubator. Geophys. Res. Lett. 35, L12602.

Silva, A., Palma, S., Oliveira, P.B., Moita, M.T., 2009. Composition and interannual variability of phytoplankton in a coastal upwelling region (Lisbon Bay, Portugal). J. Sea Res. 62, 238249.

Taylor, J.D., Berzano, M., Percy, L., Lewis, J., 2013. Evaluation of the MIDTAL microarray chip for monitoring toxic microalgae in the Orkney Islands, UK. Environ. Sci. Pollut. Res. 20, 6765-6777.

Touzet, N., Davidson, K., Pete, R., Flanagan, K., McCoy, G.R., Amzil, Z., Maher, M., Chapelle, A., Raine, R., 2010. Co-Occurrence of the West European (Gr.III) and North American (Gr.I) Ribotypes of Alexandrium tamarense (Dinophyceae) in Shetland, Scotland. Protist. 161, 370-384

Trainer, V.L., Pitcher, G.C., Reguera, B., Smayda, T.J., 2010. The distribution and impacts of harmful algal bloom species in eastern boundary upwelling systems. Prog. Oceanogr. 85, 3352.

Trainer, V.L., Bates, S.S., Lundholm, N., Thessen, A.E., Cochlan, W.P., Adams, N.G., Trick, C.G, 2012. Pseudo-nitzschia physiological ecology, phylogeny, toxicity, monitoring and impacts on ecosystem health. Harmful Algae. 14, 271-300. 
Vale, P., Sampayo, M.A.M., 2001. Domoic acid in Portuguese shellfish and fish. Toxicon. 39, 893-904.

Vale, P., Botelho, M.J., Rodrigues, S.M., Gomes, S.S., Sampayo, M.A.M., 2008. Two decades of marine biotoxin monitoring in bivalves from Portugal (1986-2006): A review of exposure assessment. Harmful Algae. 7, 11-25.

Villar-Gonzalez, A., Rodriguez-Velasco, M.L., Ben-Gigirey, B., Botana, L.M., 2007. Lipophilic toxin profile in Galicia (Spain): 2005 toxic episode. Toxicon. 49, 1129-1134.

\section{Tables and Figures}


Table 1: Comparison of testing platforms utilised in this research showing main attributes, benefits and limitations of each method. Biotoxin testing methods include multitoxin SPR biosensor, ELISA and analytical methods (HPLC-FLD and LC-MS/MS). Species identification by RNA microarray and

light microscopy are also included.

\begin{tabular}{|c|c|c|c|c|c|}
\hline \multirow{2}{*}{ Attribute } & \multicolumn{3}{|c|}{ Biotoxin Methods } & \multicolumn{2}{|c|}{ Species Methods } \\
\hline & Multitoxin SPR Biosensor & ELISA & Analytical Methods & RNA Microarray & Light Microscopy \\
\hline Analysis & $\begin{array}{c}\text { PSP, okadaic acid (and analogues) and } \\
\text { domoic acid toxins detected } \\
\text { simultaneously. }\end{array}$ & $\begin{array}{l}\text { PSP, okadaic acid (and analogues) and } \\
\text { domoic acid toxins detected by three } \\
\text { separate ELISAs. }\end{array}$ & $\begin{array}{l}\text { PSP, okadaic acid (and analogues) and } \\
\text { domoic acid toxins detected by three } \\
\text { separate methods. }\end{array}$ & $\begin{array}{l}\text { Identification of a number of toxic and } \\
\text { non-toxic algal species (as hybridised } \\
\text { on the microarray) detected } \\
\text { simultaneously. }\end{array}$ & $\begin{array}{l}\text { Identification of toxic and non-toxic } \\
\text { algal species (Edler and Elbrächter, } \\
\text { 2010) }\end{array}$ \\
\hline Sensitivity & $\begin{array}{l}\text { PSP toxins: } 0.82 \mathrm{ng} / \mathrm{ml} \\
\text { Okadaic acid: } 0.36 \mathrm{ng} / \mathrm{ml} \\
\text { Domoic acid: } 1.66 \mathrm{ng} / \mathrm{ml}\end{array}$ & $\begin{array}{l}\text { PSP toxins: } 0.01 \mathrm{ng} / \mathrm{ml} \\
\text { Okadaic acid: } 0.41 \mathrm{ng} / \mathrm{ml} \\
\text { Domoic acid: } 0.34 \mathrm{ng} / \mathrm{ml}\end{array}$ & $\begin{array}{l}\text { PSP toxins: } 2.5 \mathrm{ng} / \mathrm{ml} \\
\text { Okadaic acid: } 2.5 \mathrm{ng} / \mathrm{ml} \\
\text { Domoic acid: } 2.5 \mathrm{ng} / \mathrm{ml}\end{array}$ & $\begin{array}{l}4000 \text { cells for Alexandrium minutum } \\
\text { (McCoy et al., } \\
\text { 2014). } \\
\text { Other assays not determined. }\end{array}$ & $\begin{array}{c}100 \text { cells/ L } \\
\text { (Kegel et al., 2013) }\end{array}$ \\
\hline Specificity & $\begin{array}{c}\text { PSP toxins: STX 100\%, NEO 113\%, } \\
\text { dcNEO 100\%, dcSTX 75\%, GTX5 } \\
59 \% \text {, GTX1/4 21\%, GTX2/3 6.4\%, } \\
\text { dcGTX2/3 1\%, C1/2 1.4\% } \\
\text { Okadaic acid: OA 100\%, DTX1 68\%, } \\
\text { DTX2 65\% } \\
\text { Domoic acid: DA } 100 \%\end{array}$ & $\begin{array}{c}\text { PSP toxins: STX 100\%, NEO 1.4\%, } \\
\text { dcNEO 0.5\%, dcSTX 19.2\%, GTX5 } \\
\text { 26.2\%, GTX1/4 <0.1\%, GTX2/3 5.6\%, } \\
\text { dcGTX2/3 0.2\%, C1/2 0.2\% } \\
\text { Okadaic acid: OA 100\%, DTX1 78\%, } \\
\text { DTX2 2.6\% } \\
\text { Domoic acid: DA } 100 \%\end{array}$ & $\begin{array}{c}\text { PSP toxins: Very specific detecting } \\
\text { STX, NEO, dcNEO, dcSTX, GTX5, } \\
\text { GTX1/4, GTX2/3, dcGTX2/3 and C1/2 } \\
\text { Okadaic acid: } \\
\text { Very specific detecting OA, DTX1 and } \\
\text { DTX2 } \\
\text { Domoic acid: Very specific detecting } \\
\text { DA and DA isomers. }\end{array}$ & $\begin{array}{l}\text { At present, } 136 \text { probes for various } \\
\text { toxic algal species at various } \\
\text { taxonomic levels are spotted onto the } \\
\text { current generation of the MIDTAL } \\
\text { microarray. }\end{array}$ & $\begin{array}{l}\text { Specific. Identification of all taxa to the } \\
\text { genus and in most cases species level } \\
\text { (exception Pseudo-nitzschia and } \\
\text { Alexandrium in some cases) }\end{array}$ \\
\hline Ease of use & $\begin{array}{l}\text { Method is relatively easy to use but } \\
\text { will require initial training. }\end{array}$ & $\begin{array}{l}\text { Method is relatively easy to use but } \\
\text { will require initial training. }\end{array}$ & $\begin{array}{c}\text { Skilled personnel with previous } \\
\text { experience in HPLC and LC-MS/MS } \\
\text { methods for operation and interpretation } \\
\text { of complex toxin profiles will be } \\
\text { required. }\end{array}$ & $\begin{array}{l}\text { Method is laborious, requires trained } \\
\text { personnel and a significant amount of } \\
\text { hands-on time. }\end{array}$ & $\begin{array}{l}\text { Method requires highly trained/ skilled } \\
\text { personnel with phytoplankton } \\
\text { taxonomic skills. }\end{array}$ \\
\hline
\end{tabular}




\begin{tabular}{|c|c|c|c|c|c|}
\hline $\begin{array}{c}\text { Sample } \\
\text { Preparation }\end{array}$ & $\begin{array}{l}\text { Filter water sample and cell lysis of } \\
\text { algal cells (to extract cell bound toxins) } \\
\text { using a freeze-thaw and glass beads } \\
\text { protocol. Clean up by filtering } \\
\text { supernatant before direct analysis by } \\
\text { multitoxin SPR. }\end{array}$ & $\begin{array}{l}\text { Filter water sample and cell lysis of } \\
\text { algal cells (to extract cell bound toxins) } \\
\text { using a freeze-thaw and glass beads } \\
\text { protocol. Clean up by filtering } \\
\text { supernatant before direct analysis by } \\
\text { ELISA. }\end{array}$ & $\begin{array}{l}\text { Filter water sample and cell lysis of } \\
\text { algal cells (to extract cell bound toxins) } \\
\text { using a freeze-thaw and glass beads } \\
\text { protocol. Clean up by filtering } \\
\text { supernatant before direct analysis by } \\
\text { LC-MS/MS for domoic acid and } \\
\text { okadaic acid toxins. PSP toxin analysis } \\
\text { requires a further oxidation step of } \\
\text { samples with both periodate and } \\
\text { peroxide oxidations of samples for } \\
\text { analysis by HPLC-FLD. }\end{array}$ & $\begin{array}{l}\text { Filter water sample and cell lysis of } \\
\text { algal cells (to extract RNA) using a } \\
\text { glass beads protocol. RNA is extracted } \\
\text { using BCP, chloroform and } \\
\text { isopropanol followed by clean-up } \\
\text { using ammonium acetate. RNA is } \\
\text { labelled and fragmented and finally } \\
\text { hybridized onto a microarray for } \\
\text { species identification. }\end{array}$ & $\begin{array}{l}\text { Minimal sample preparation. Water } \\
\text { sample (0.1-1 L) is preserved using } \\
\text { lugols solution for cell enumeration } \\
\text { using light microscopy. A variable } \\
\text { volume is allowed to settle and used for } \\
\text { counting using an Utermöhl chamber } \\
\text { (Edler and Elbrächter, 2010) }\end{array}$ \\
\hline $\begin{array}{l}\text { Speed of analysis } \\
\text { (24 samples) }\end{array}$ & $\begin{array}{l}\text { Extraction: } 2 \mathrm{hr} \\
\text { Analysis: } 5 \mathrm{hr}\end{array}$ & $\begin{array}{c}\text { Extraction: } 2 \mathrm{hr} \\
\text { Analysis: } 3 \text { hr (okadaic acid and } \\
\text { domoic acid) or overnight (saxitoxin) }\end{array}$ & $\begin{array}{c}\text { Extraction: } 2 \mathrm{hr} \\
\text { Analysis: } 12-24 \mathrm{hr} \text { (including } \\
\text { interpretation) }\end{array}$ & $\begin{array}{c}\text { Extraction: } 8-12 \mathrm{hr} \\
\text { Analysis: } 2-6 \mathrm{hr}\end{array}$ & $\begin{array}{l}\text { Settling time: } 24 \mathrm{hr} \\
\text { Analysis: } 48 \mathrm{hr}\end{array}$ \\
\hline Portability & Not possible & Not possible & Not possible & Not possible & Not possible \\
\hline Benefits & $\begin{array}{l}\text { Relatively fast result, highly sensitive, } \\
\text { highly specific, cost effective, high } \\
\text { throughput screening, real time results } \\
\text { and multiplex analysis of three toxins. }\end{array}$ & $\begin{array}{l}\text { Highly sensitive, highly specific, cost } \\
\text { effective, high throughput screening. }\end{array}$ & $\begin{array}{c}\text { Accurate identification and } \\
\text { quantification. }\end{array}$ & $\begin{array}{l}\text { Highly sensitive, highly specific, cost } \\
\text { effective, high throughput screening. } \\
\text { Multiplexing a number of potentially } \\
\text { toxic algal species from one sample. }\end{array}$ & $\begin{array}{l}\text { No expensive equipment required } \\
\text { except for a microscope. Quite specific } \\
\text { and can also detect taxa that are new } \\
\text { for the region, not yet cultured and } \\
\text { sequenced, or not known to be toxic }\end{array}$ \\
\hline Limitations & Biosensor is expensive & $\begin{array}{l}\text { Time consuming, interpretation and } \\
\text { analysis of results is required. No } \\
\text { multiplexing possibility therefore three } \\
\text { ELISAs will be required. }\end{array}$ & $\begin{array}{l}\text { Equipment is expensive, requires fully } \\
\text { trained personnel to operate equipment } \\
\text { and interpret complex toxin profile } \\
\text { results for those with certified standards } \\
\text { available. }\end{array}$ & $\begin{array}{l}\text { Method is laborious with long sample } \\
\text { preparation steps before sample is } \\
\text { ready for analysis. Equipment required } \\
\text { for sample preparation and microarray } \\
\text { scanning is expensive. }\end{array}$ & $\begin{array}{c}\text { Time consuming and is based on } \\
\text { species identification using cell } \\
\text { morphology. Each sample requires on } \\
\text { average two hours to examine therefore } \\
\text { allowing only } 20 \text { samples per week per } \\
\text { person to be analysed. The } \\
\text { morphological similarity between } \\
\text { different species within phytoplankton } \\
\text { genera means that light microscopy } \\
\text { alone is often insufficient to give } \\
\text { definite species identifications and thus } \\
\text { assess the potential toxicity of the water }\end{array}$ \\
\hline
\end{tabular}


Table 2: Number of positive seawater samples detected when analysed by the three toxin testing platforms $(n=256)$, RNA microarray $(n=145)$ and light microscopy $(\mathrm{n}=177)$. Samples were analysed for domoic acid, okadaic acid and PSP toxins for each partner within the MIDTAL project by multitoxin SPR, ELISA and analytical (HPLC-FLD or LC-MS/MS). Potentially toxic species present when analysed by RNA microarray and light microscopy are also presented.

\begin{tabular}{|c|c|c|c|c|c|c|c|c|c|c|c|c|c|c|c|c|c|}
\hline \multirow[b]{2}{*}{ Partner } & \multirow[b]{2}{*}{ Country } & \multirow{2}{*}{$\begin{array}{c}\text { No. of } \\
\text { samples }\end{array}$} & \multicolumn{5}{|c|}{$\underline{\text { PSP toxins }}$} & \multicolumn{5}{|c|}{ OA toxins } & \multicolumn{5}{|c|}{ DA toxins } \\
\hline & & & $\begin{array}{l}\text { Multi } \\
\text { SPR }\end{array}$ & ELISA & HPLC & RNA & $\begin{array}{c}\text { Cell } \\
\text { counts }\end{array}$ & $\begin{array}{l}\text { Multi } \\
\text { SPR }\end{array}$ & ELISA & $\begin{array}{c}\text { LC- } \\
\text { MS/MS }\end{array}$ & RNA & $\begin{array}{c}\text { Cell } \\
\text { counts }\end{array}$ & $\begin{array}{c}\text { Multi } \\
\text { SPR }\end{array}$ & ELISA & $\begin{array}{c}\text { LC- } \\
\text { MS/MS }\end{array}$ & RNA & $\begin{array}{c}\text { Cell } \\
\text { counts }\end{array}$ \\
\hline MBA & France & 9 & 1 & 9 & 0 & 2 & 6 & 0 & 4 & 0 & 6 & 8 & 1 & 2 & 1 & 6 & 6 \\
\hline SZN & Italy & 23 & 11 & 23 & 2 & 9 & 2 & 7 & 10 & 1 & 10 & 3 & 20 & 18 & 13 & 20 & 20 \\
\hline LNU & Sweden & 24 & 5 & 21 & 4 & 1 & 7 & 5 & 10 & 5 & 2 & 19 & 2 & 9 & 5 & 14 & 15 \\
\hline IEO & Spain & 28 & 21 & 27 & 12 & 2 & 5 & 26 & 28 & 27 & 2 & 9 & 27 & 28 & 26 & 2 & 9 \\
\hline NUIG & Ireland & 59 & 40 & 54 & 17 & 13 & 17 & 45 & 38 & 7 & 13 & 16 & 45 & 43 & 11 & 23 & 13 \\
\hline UO & Norway & 21 & 2 & 13 & 0 & 8 & 5 & 10 & 10 & 3 & 6 & 15 & 7 & 15 & 3 & 4 & 18 \\
\hline UW & UK & 22 & 6 & 19 & 2 & 10 & 9 & 10 & 11 & 2 & 11 & 5 & 11 & 15 & 7 & 19 & 15 \\
\hline INT & Spain & 70 & 36 & 63 & 20 & 9 & 15 & 46 & 45 & 34 & 6 & 27 & 50 & 63 & 47 & 21 & 41 \\
\hline & Total & 256 & 122 & 229 & 57 & 54 & 66 & 149 & 156 & 79 & 56 & 102 & 163 & 193 & 113 & 109 & 137 \\
\hline & $\%$ & 100 & 48 & 89 & 22 & 37 & 37 & 58 & 61 & 31 & 39 & 58 & 64 & 75 & 44 & 75 & 77 \\
\hline
\end{tabular}


Table 3: Statistical $2 \times 2$ comparative analysis of the qualitative results for each testing platform (multitoxin SPR, ELISA, analytical, RNA and cell counts) showing the overall agreement between methods for each toxin family.

\begin{tabular}{|c|c|c|c|c|c|c|c|c|c|c|c|c|c|c|}
\hline \multirow{2}{*}{ Toxin } & \multirow{2}{*}{\multicolumn{2}{|c|}{ Testing platform }} & \multicolumn{3}{|c|}{ ELISA } & \multicolumn{3}{|c|}{ Analytical } & \multicolumn{3}{|c|}{ RNA } & \multicolumn{3}{|c|}{ Cell Counts } \\
\hline & & & + & - & Total & + & - & Total & + & - & Total & + & - & Total \\
\hline \multirow{16}{*}{$\begin{array}{l}\text { Domoic } \\
\text { acid }\end{array}$} & & + & 40 & 51 & 91 & 77 & 14 & 91 & 23 & 40 & 63 & 24 & 49 & 73 \\
\hline & Multi & - & 22 & 140 & 162 & 64 & 98 & 162 & 5 & 69 & 74 & 24 & 74 & 98 \\
\hline & SPR & Total & 62 & 191 & 253 & 141 & 112 & 253 & 28 & 109 & 137 & 48 & 123 & 171 \\
\hline & & Overall agreement $(\%)$ & & & 71 & & & 69 & & & 67 & & & 57 \\
\hline & & + & & & & 62 & 0 & 62 & 15 & 23 & 38 & 14 & 27 & 41 \\
\hline & EI ISA & - & & & & 79 & 112 & 191 & 13 & 86 & 99 & 36 & 97 & 133 \\
\hline & ELISA & Total & & & & 141 & 112 & 253 & 28 & 109 & 137 & 50 & 124 & 174 \\
\hline & & Overall agreement (\%) & & & & & & 69 & & & 74 & & & 64 \\
\hline & & + & & & & & & & 24 & 59 & 83 & 34 & 61 & 95 \\
\hline & Anglyticol & - & & & & & & & 4 & 50 & 54 & 14 & 62 & 76 \\
\hline & Analytical & Total & & & & & & & 28 & 109 & 137 & 48 & 123 & 171 \\
\hline & & Overall agreement $(\%)$ & & & & & & & & & 54 & & & 56 \\
\hline & & + & & & & & & & & & & 14 & 14 & 28 \\
\hline & RNA & - & & & & & & & & & & 26 & 83 & 109 \\
\hline & KNA & Total & & & & & & & & & & 40 & 97 & 137 \\
\hline & & Overall agreement $(\%)$ & & & & & & & & & & & & 71 \\
\hline \multirow{16}{*}{$\begin{array}{c}\text { Okadaic } \\
\text { acid } \\
\text { (DTX1/ } \\
\text { DTX2) }\end{array}$} & & + & 62 & 39 & 101 & 92 & 9 & 101 & 45 & 24 & 69 & 38 & 42 & 80 \\
\hline & Multi & - & 37 & 115 & 152 & 84 & 68 & 152 & 35 & 32 & 67 & 33 & 58 & 91 \\
\hline & SPR & Total & 99 & 154 & 253 & 176 & 77 & 253 & 80 & 56 & 136 & 71 & 100 & 171 \\
\hline & & Overall agreement (\%) & & & 70 & & & 63 & & & 57 & & & 56 \\
\hline & & + & & & & 94 & 5 & 99 & 44 & 20 & 64 & 41 & 36 & 77 \\
\hline & & - & & & & 82 & 72 & 154 & 36 & 36 & 72 & 31 & 66 & 97 \\
\hline & ELISA & Total & & & & 176 & 77 & 253 & 80 & 56 & 136 & 72 & 102 & 174 \\
\hline & & Overall agreement $(\%)$ & & & & & & 66 & & & 59 & & & 61 \\
\hline & & + & & & & & & & 68 & 39 & 107 & 65 & 64 & 129 \\
\hline & & - & & & & & & & 12 & 17 & 29 & 6 & 36 & 42 \\
\hline & Analytical & Total & & & & & & & 80 & 56 & 136 & 71 & 100 & 171 \\
\hline & & Overall agreement (\%) & & & & & & & & & 63 & & & 59 \\
\hline & & + & & & & & & & & & & 40 & 40 & 80 \\
\hline & RNA & - & & & & & & & & & & 19 & 37 & 56 \\
\hline & NIVA & Total & & & & & & & & & & 59 & 77 & 136 \\
\hline & & Overall agreement $(\%)$ & & & & & & & & & & & & 57 \\
\hline \multirow{16}{*}{$\begin{array}{l}\text { PSP } \\
\text { toxins }\end{array}$} & & + & 21 & 109 & 130 & 129 & 1 & 130 & 59 & 29 & 88 & 75 & 31 & 106 \\
\hline & Multi & - & 2 & 121 & 123 & 67 & 56 & 123 & 27 & 22 & 49 & 35 & 30 & 65 \\
\hline & SPR & Total & 23 & 230 & 253 & 196 & 57 & 253 & 86 & 51 & 137 & 110 & 61 & 171 \\
\hline & & Overall agreement (\%) & & & 56 & & & 73 & & & 59 & & & 61 \\
\hline & & + & & & & 23 & 0 & 23 & 10 & 3 & 13 & 16 & 5 & 21 \\
\hline & & - & & & & 173 & 57 & 230 & 76 & 48 & 124 & 95 & 58 & 153 \\
\hline & ELISA & Total & & & & 196 & 57 & 253 & 86 & 51 & 137 & 111 & 63 & 174 \\
\hline & & Overall agreement (\%) & & & & & & 32 & & & 42 & & & 43 \\
\hline & & + & & & & & & & 74 & 46 & 120 & 98 & 47 & 145 \\
\hline & Anolyticol & - & & & & & & & 12 & 5 & 17 & 12 & 14 & 26 \\
\hline & Anailycal & Total & & & & & & & 86 & 51 & 137 & 110 & 61 & 171 \\
\hline & & Overall agreement $(\%)$ & & & & & & & & & 58 & & & 65 \\
\hline & & + & & & & & & & & & & 65 & 21 & 86 \\
\hline & RNA & - & & & & & & & & & & 25 & 26 & 51 \\
\hline & RIVA & Total & & & & & & & & & & 90 & 47 & 137 \\
\hline & & Overall agreement (\%) & & & & & & & & & & & & 66 \\
\hline
\end{tabular}




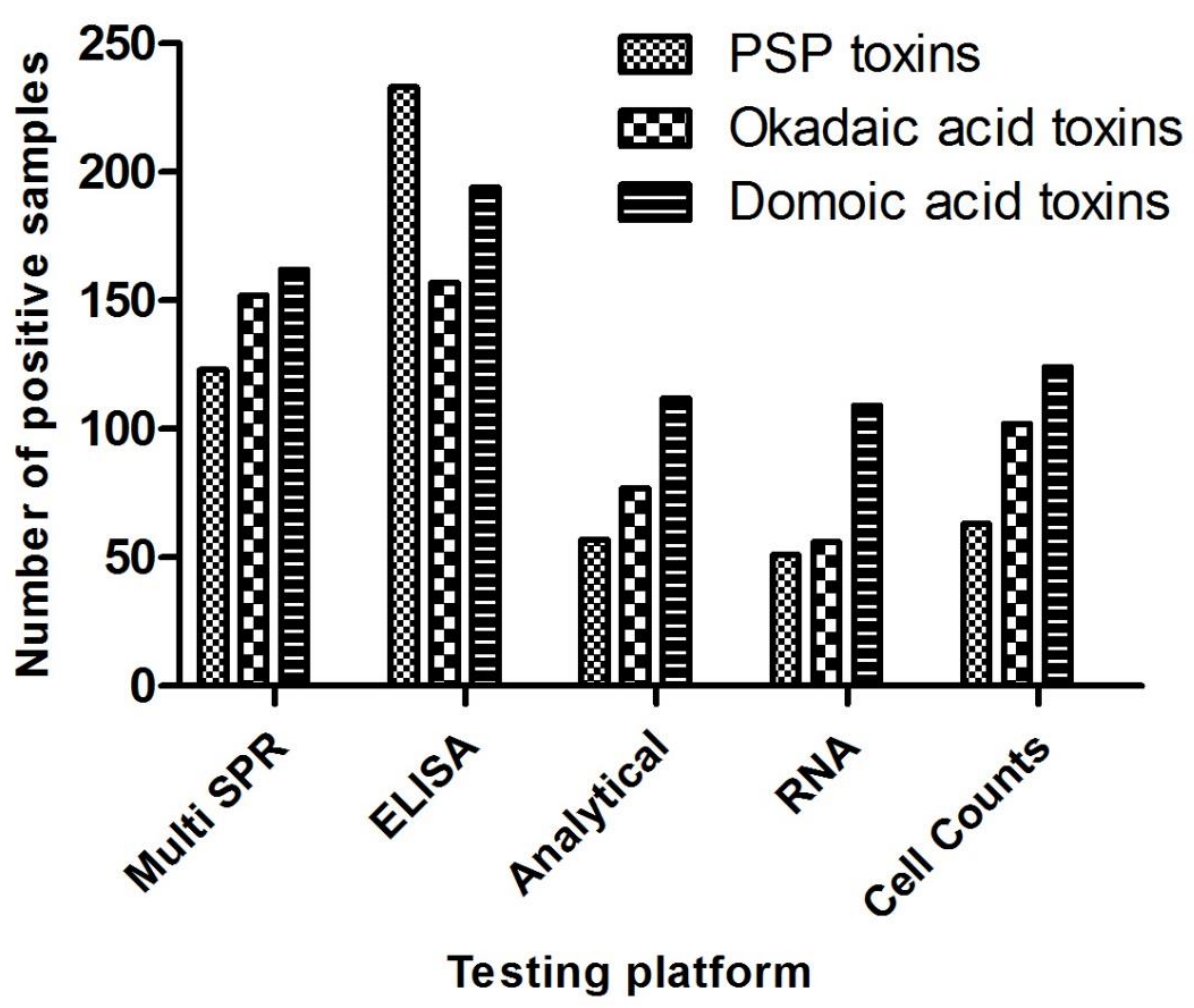

Figure 1: Number of positive samples detected by each testing platform (Multitoxin SPR, ELISA, analytical, RNA microarray and cell counts) for PSP toxins, okadaic acid toxins and domoic acid toxins $(\mathrm{n}=256)$. 
